\title{
LEGAL PROTECTION CONCEPT: SEPARATE MAINTENANCE FOR THE THIRD PARTY IN PRENUPTIAL AGREEMENT
}

\author{
Sri Subekti \\ Doctorate Program of Law, University of 17 Agustus 1945 Semarang, Indonesia \\ Liliana Tedjosaputro \\ Faculty of Law, University of 17 Agustus 1945 Semarang, Indonesia \\ Mashari \\ Faculty of Law, University of 17 Agustus 1945 Semarang, Indonesia
}

\begin{abstract}
This research aims to establish the regulation concept of the procedures of making marital arrangements while in the marital period. The problem of this research is why there is a legal protection problem third party to the agreement of the equitable postmarital assets separation. Method of empirical juridical is the operation of law in the society which is seen as a real part of the social system related to its empirical reality in the society. The research findings show that the separation of the post-marital assets to the third parties affected the properties of husband and wife, all parties, in this case, is husband-wife and the third party, are bound to the content of the marital agreement and must carry out their rights and obligations as agreed in the agreement. The legal protection of the third party to the separation agreement of the post-marital assets will be binding when the marital agreement deed is made before a Notary, furthermore, the establishment is requested to the authorized District Court and recorded at the Office of Religious Affairs for Muslims, meanwhile for non-Muslims, it is recorded at the Population and Civil Registration Office according to its legal subject.
\end{abstract}

Keywords: Legal Protection; the Agreement of Assets Separation; Marriage.

Cite this Article: Sri Subekti, Liliana Tedjosaputro and Mashari, Legal Protection Concept: Separate Maintenance for the Third Party in Prenuptial Agreement. International Journal of Civil Engineering and Technology (IJCIET), 11(1), 2020, pp.233-241.

https://iaeme.com/Home/issue/IJCIET?Volume=11\&Issue=1

\section{INTRODUCTION}

The need for society in marital law is very important, especially compared to the past few decades. The existing trend indicates the increasing number of personal needs (Jules and 
Nicola, 2014). (Swennen, 2015). At the same time, a private or personal relationship still remain as an area where the personal needs are seen with significantly suspicious angle, and most marital laws are established by mandatory rules and based on the status (Bix, 2012). As a part of a series of works that reflects an agreement in the context of marital laws, this paper reflects a very different treatment from the agreement in the post-marital agreement of assets separation. (Ii et al., no date)

In the previous studies which used Anglo-America course, the term 'legal power' was used where Europeans used 'competency'. It is very simple, in which we can say that the jurisdiction is referring to the legal power and where the said law is applicable. This causes challenging questions such as the extent to which a country can decide on the boundaries of international jurisdiction or supranational in its own territory and the extent to which international court can decide this. (Hildebrandt, 2019)(Siliquini-Cinelli and Hutchison, 2017)(Efe, 2019). This case is a part of the research of this paper, in which the marriage of people with different citizenship becomes the main discussion.

The Unitary State of the Republic of Indonesia based on The 1945 Constitution of the Republic of Indonesia is defined strictly as a state of law that guarantees legal certainty, order, and protection with truth and justice as the core. Legal protection for the third party in the separation of assets of post-marital agreement can make a deed of the marital agreement. Post-marital joint assets merged between husband and wife without a strict separation. An Indonesian citizen (WNI) who marries a foreign citizen (WNA), the assets he gets after marriage become joint assets, and a prenuptial agreement is needed to separate it. Based on Law Number 1 of 1974 concerning Marriage in Article 58 states that an Indonesian citizen of intermarriage can choose to retain or lose his citizenship.

According to Wirjono,[1] marriage is an agreement if a woman and a man agree to marry each other; it means they promise to each other that they will adhere to the applicable legal regulations about each other's rights and obligations during and after living together, also regarding their descendants' position within the society (Prodjodikoro, 1981). A marital agreement is defined as a legal relationship regarding assets between two parties, in which one party promises or is deemed promised to do something, while the other party has the right to demand the implementation of the agreement. The word agreement as to the legal relationship, if related to the word marriage then it includes the discussion about marital agreement, as a noble agreement between the groom and the bride. People with intermarriage do not have those rights, but based on Law Number 1 of 1974 concerning Marriage, those with intermarriage who still choose as an Indonesian citizen still considered as single citizens. The inconsistency in the implementation of this regulation shows that there is an inaccurate application of the regulation process due to the number of rules that are not consistently and continuously regulated both in Law Number 5 of 1960 concerning Basic Principles of Agrarian Law (UUPA) and Law Number 1 of 1974 concerning Marriage.

The intermarriage proposed by Mrs. Ike Farida to the Constitutional Court (MK) Number 69/PUU-XII/2015 which in its petitum towards Article 35 paragraph (1) of Law Number 1 of 1974 concerning Marriage, in this case, Mrs. Ike Farida asks that the Constitutional Court interprets "joint assets" to "joint assets except for the properties in the form of HM (Right of Ownership) and HGB (Building Rights) owned by a WNI who married to a WNA".[2] The issues from Mrs. Ike Farida's plea are: (i). The plea is only directed to Article 35 paragraph (1) of Law Number 1 of 1974 concerning Marriage, while Article 21 paragraph (3) regulates the mixing of assets in connection with Right of Ownership (HM) due to the intermarriage between WNI and WNA, if Mrs. Ike Farida's plea is granted, it would only cause clashes between legal norms jika permohonan; (ii) The pleas proposed only include HM and Building Rights (HGB), while the title rights over land are intended only for WNI, not only HM and 
HGB, but also includes HGU (Cultivation Rights Title). If Mrs. Ike Farida's plea is granted, then there will be a clash of the concept of mixing assets in the context of land. This research aims to develop the legal protection concept of the third party for the separation agreement of the post-marital assets through a drafting deed of a marital agreement that has not been regulated in Indonesian laws and regulations. This is intended to provide legal certainty; legal use and justice for husband and wife who have been married and have not made a prenuptial agreement and made a post-marital marriage agreement to keep their marital assets safe.

\section{RESEARCH METHOD}

The research method used in this research is empirical juridical approach, namely to deepen and expand the object under study because, in this research, it will be seen how the law works in society and how the law interacts with the society, law is not only seen as a normative entity that is independent or esoteric, rather it must be seen as a real part of the social system which is related to other social variables so that a marital agreement in the marital period towards the third party needs to be researched from its law aspect also empirical reality in the society $(\mathrm{Li}, 2014)$. The first step of empirical juridical research is to formulate the research questions. The research questions generally must be in accordance with the rules that must be relevant in the real world. It is really important that this research seeks to provide practical and important implications for society. The question must contribute to the body of existing scientific literature. Referring to a series of established related studies, the researchers can help avoid significant problems such as duplicating or ignoring previous researches (Atwood et al., 2013)(Ii et al., no date).

\section{ASSETS SEPARATION POST MARITAL AGREEMENT}

A marital agreement is an agreement that is made by the future husband and wife contains agreements regarding assets or other agreements that are deemed necessary by both parties. Sudikno Mertokusomo[3] defines marital agreement as an agreement that is made before a wedding is held and bound both parties of groom and bride and applies after the wedding is held. The third-party who becomes creditors should receive legal protection of post-marital agreement (Mertokusumo, 1988). It is very important to know the position of husband and wife assets related to the certainty of settled payment debt. If a husband and wife marry with the unity of marital assets, then the debt that is made by them can be paid off from their joint assets. Otherwise, if there is a marital agreement, then the payment of the debt is the responsibility of the party that makes the agreement.

The third party legal protection to the marital assets separation agreement changes due to Constitutional Court Decision Number 69/PUU-XII/2015 which allows the making of an agreement of marital assets separation that brings an impact to the relation with the third party because of the legal status of the marital assets that are previously united becomes separated. The Constitutional Court's decision is final, ever since then everything that has been mentioned in the ruling of the Constitutional Court can be implemented even though the procedures have not been made yet. In this case, the implementation of the said Constitutional Court's Decision follows the general rules as well as the existing law principles. The born of the Decision of Constitutional Court Number 69/PUU-XII/2015 is based on the existence of constitutional rights of Indonesian citizens who are disadvantaged by the previous provision that stated a marital agreement an only be made before the wedding took place. The said decision was intended to accommodate those who are tied by a wedding but didn't make a marital agreement because of the lack of information. The Constitutional Court's Decision was born based on the consideration of a sense of justice for all Indonesian citizens. The procedures of making a marital agreement during a marriage will potentially harmful to the 
constitutional rights of other Indonesian citizens, especially those who are creditors. The protection of marital assets from the debtor aims to avoid bad faith from married couples who make marital agreements. A marriage that makes a marital agreement will have another impact on the third party, for example, agreements to creditors, in this case, the third party is faced with 2 or 3 groups of marital assets and the third party must understand which assets can be accounted for, in relation to their debt.[4] A marital agreement, it may happen that a certain item is an item outside the property of the union. In a marriage with a marital agreement, there are two or three groups of assets: (i). The joint assets; (ii). The personal assets of husband or wife; (iii). The separate assets of husband and wife, without joint assets (Satrio, 1991).

\section{BUILDING THE CONCEPT OF THIRD PARTY LEGAL PROTECTION TO THE ASSETS SEPARATION POST MARITAL AGREEMENT}

A marital agreement that is made during the marriage, which for some reasons between the husband and wife just made a marriage agreement, as for such case can be justified by law on the basis that such an agreement must be preceded by submitting an application to the authorized court in order to get a decision from the judge, such as the following court's decisions: (1) Court Order of East Jakarta Number 207/Pdt/P/2005/ PN.Jkt.Tim., dan (2) Court Order of East Jakarta Number 459/Pdt/P/2007/PN.Jkt.Tim.

A marital agreement is requested to the District Court, then the husband and wife can make an agreement deed of post-marital assets separation in front of a Notary. Based on Article 15 paragraph (1) of Law Number 2 of 2014 concerning Amendments to Law Number 30 of 2004 concerning Position of Notary, it is mentioned that Notary has the authority to make an authentic deed regarding all acts, agreements, and provisions required by statutory regulations and/or that is desired by the interested parties to be stated in an authentic deed, guarantees the certainty of the date of making the deed, keeps the deed, gives a grosse, a copy and a citation of deeds, all of those, as long as the making of the deeds is not also assigned or excluded to other officials or other people that are determined by law.

Post-marital marriage agreements that have already been approved by the court can be interpreted that such an agreement is carried out at the time of the wedding takes place by getting an order from the court first. The authority of Notary as a general officer in the drafting of the marital agreement that has been made in front of the Notary is then registered to the institute that has been granted authorized by the legislation to record it. A marital agreement has to be registered to the Office of Religious Affairs (KUA) for muslims, while for non-muslims, it has to be registered to Population and Civil Registration Office (DISPENDUKCAPIL) according to its legal subject.[5] If the said deed of marital agreement is not registered then it is not legally binding for third parties.

After the issuance of the Constitutional Court's decision Number 69/PUU-XII/2015 on $21^{\text {st }}$ of March 2016, there has been a change related to the making of a marital agreement, the said decision is based on the request of an Indonesian citizen who did intermarriage and held the wedding without making a marital agreement. As time went by, the said couple wanted to buy a house/flat but because of the the regulations that apply in the context of national land law are in Law Number 5 of 1960 concerning Basic Principles of Agrarian Law (UUPA) adheres to the principle of nationality, which means that only Indonesian citizens who are allowed to have land rights in Indonesia. The said intermarriage couple then submitted a request of. constitutional review (pengujian konstitusional) to the MK because they have felt disadvantaged by the existence of Article 21 paragraph (1), and paragraph (3), Article 36 
paragraph (1) UUPA, Article 29 paragraph (1), paragraph (3), paragraph (4), and Article 35 paragraph (1) Law Number 1 of 1974 concerning Marriage.

The opinion of the Constitutional Court in its legal considerations states that: strictly speaking, the existing provisions only regulate marital agreements made before or at the time of the marriage, whereas in reality there is a phenomenon of husband and wife, who for some reason, have just felt the need to make a marital agreement during marriage. So far, it is in accordance with Article 29 of Law Number 1 of 1974 concerning Marriage that the agreement has to be done before a wedding and has to be put in a Notary deed.

The recording of marital agreements that are made at the time of the marriage will certainly face the same obstacles as long as there are no new provisions that regulate the procedure for recording the marital agreement that is made at the time the marriage takes place. To overcome these obstacles, surely the Minister of Home Affairs must immediately issue regulations related to the recording of marital agreements, including the recording of marital agreements made throughout marriage, which immediately followed by issuing the technical instructions about the recording of the marital agreement. As long as there is no provision about the recording of marital agreements made during the marriage then surely the recording cannot be done yet, and if the marital agreement has not been recorded, it is not binding on any third party and only applies between the parties.

The making of a marital agreement deed generally results in legal consequences for the status of the assets as well as for related third parties. The results of research conducted by the writers about Court Order Number 207/Pdt.P/2005/PN.Jkt.Tim and Court Order Number 459/Pdt.P/2007PN.Jkt.Tim are that the writers found legal consequences from those Court Orders. The legal consequences for the status of the assets of both Court Order Number 207/Pdt.P/2005/PN.Jkt.Tim and Court Order Number 459/Pdt.P/2007PN.Jkt.Tim are the separation of the assets, those which used to be joint assets become each party's assets and other assets, which later arise after the date of the order remain separate from one another, so there is no longer joint property status.

Table 1 Concept of Third Party Legal Protection to the Assets Separation Post Marital Agreement

\begin{tabular}{|c|l|l|}
\hline NO. & \multicolumn{1}{|c|}{ EXISTING } & \multicolumn{1}{|c|}{ IDEAL } \\
\hline 1. & $\begin{array}{l}\text { There is no regulation of marital agreements } \\
\text { asset separation after marriage so it opens up a } \\
\text { wide space for interpretation for now. }\end{array}$ & $\begin{array}{l}\text { Establishing the Drafting Law of Marital } \\
\text { Agreements Assets Separation after Marriage } \\
\text { into the Marriage Law. }\end{array}$ \\
\hline 2. & $\begin{array}{l}\text { Notary as a state official by law has the } \\
\text { authority to make marital agreements not only } \\
\text { to those who make before a wedding after } \\
\text { Constitutional Court Decision } \\
\text { No.69/PUU/XII/2015. }\end{array}$ & $\begin{array}{l}\text { Constitutional Court Decision } \\
\text { No.69/PUU/XII/2015 as a base for Notary to } \\
\text { make marital agreements after a wedding. }\end{array}$ \\
\hline 3. & $\begin{array}{l}\text { Marital Agreements in accordance to Article } \\
\text { 56 Civil Criminal Code (KUHP Perdata) to } \\
\text { fulfill the principle of Publicity must be } \\
\text { registered by the District Court. }\end{array}$ & $\begin{array}{l}\text { Marital Agreements that are made by Notary } \\
\text { must be recorded to the Civil Registry Office } \\
\text { so there will be legal protection and certainty } \\
\text { towards third parties. }\end{array}$ \\
\hline 4. & $\begin{array}{l}\text { The requirements of making a deed of marital } \\
\text { agreements before a wedding are ID card } \\
\text { KTP), Family Register (KK), Birth } \\
\text { Certificate, and Statement of assets Inventory } \\
\text { of each future husband and/or future wife with } \\
\text { Rp 6,000.00 duty stamped. }\end{array}$ & $\begin{array}{l}\text { The requirements of making a deed of marital } \\
\text { agreements before a wedding are ID card } \\
\text { KTP), Family Register (KK), Birth }\end{array}$ \\
$\begin{array}{l}\text { Kertificate, Marriage Certificate, Annual Tax } \\
\text { Return, Statement of Validity of Assests } \\
\text { Inventory documents of each future husband } \\
\text { and/or future wife with Rp 6,000.00 duty } \\
\text { stamped, through Public Accountant, } \\
\text { announced on the newspaper for 7 days, if } \\
\text { there is no objection then Notary can make } \\
\text { the deed, Statement of Husband and Wife to }\end{array}$ \\
\hline
\end{tabular}




\begin{tabular}{|c|c|c|}
\hline & & $\begin{array}{l}\text { obey it, and responsible for the risks that may } \\
\text { happen. }\end{array}$ \\
\hline 5. & $\begin{array}{l}\text { Article } 29 \text { paragraph (1) Law Number } 1 \text { of } \\
1974 \text { concerning Marriage states that marital } \\
\text { agreement only can be made before the } \\
\text { marriage. }\end{array}$ & $\begin{array}{l}\text { After Constitutional Court Decision } \\
\text { No.69/PUU/XII/2015, the provisions of } \\
\text { Article } 29 \text { paragraph (1) Law Number } 1 \text { of } \\
1974 \text { concerning Marriage has been changed } \\
\text { to: Before or during marriage of both parties } \\
\text { with mutual agreement, a written agreement } \\
\text { can be ratified by a marriage registrar or } \\
\text { notary, after applied to the third party and as } \\
\text { long as the third party involved. }\end{array}$ \\
\hline 6. & $\begin{array}{l}\text { Based on Article } 35 \text { paragraph (1) Law } \\
\text { Number } 1 \text { of } 1974 \text { concerning Marriage, assets } \\
\text { that are obtained in marriage period become } \\
\text { joint assets, so that later on if one of the } \\
\text { couples wants to sell or transfer the assets } \\
\text { obtained during the marriage period must } \\
\text { obtain prior approval from their partner. }\end{array}$ & $\begin{array}{l}\text { Based on this Post Marital Assets Separation } \\
\text { Agreement, there is clarity regarding the } \\
\text { ownership of the assets of husband and wife. }\end{array}$ \\
\hline 7. & $\begin{array}{l}\text { Based on Article } 29 \text { paragraph (1) Law } \\
\text { Number } 1 \text { of } 1974 \text { concerning Marriage, the } \\
\text { agreement is ratified by a marriage registrar or } \\
\text { notary. }\end{array}$ & $\begin{array}{l}\text { Based on Post Marital Agreement, it has to } \\
\text { be registered to fulfill the principle of } \\
\text { Publicity of the said agreement to the third } \\
\text { party (besides the couple) knows and obey } \\
\text { the rules in the agreement that is made by the } \\
\text { couple. This marita agreement has to fulfill } \\
\text { five principles as follows: (1) the agreement } \\
\text { is made during the marriage period; (2) } \\
\text { mutual agreement; (3) written; (4) ratified by } \\
\text { a marriage registrar or notary; and (5) applies } \\
\text { to the third party as long as they are involved. }\end{array}$ \\
\hline 8. & $\begin{array}{l}\text { The regulations of Marital Agreements Asset } \\
\text { Separation before Constitutional Court } \\
\text { Decision No. 69/PUU/XII/2015 are based on } \\
\text { Civil Criminal Code (KUHP Perdata), Law } \\
\text { Number } 1 \text { of } 1974 \text { concerning Marriage, } \\
\text { Compilation of Islamic Law. }\end{array}$ & $\begin{array}{l}\text { The regulations of Marital Agreements Asset } \\
\text { Separation before Constitutional Court } \\
\text { Decision No. 69/PUU/XII/2015 on: } \\
\text { a. (2015-2017) The order was based on the } \\
\text { Court Order then recorded in the Office of } \\
\text { Religious Affairs for muslims and Civil } \\
\text { Registry Office for non-muslims to bind the } \\
\text { related third parties. } \\
\text { b. } 2017 \text {, after Circular Letter Number was } \\
\text { issued based on the recording at the Office of } \\
\text { Religious Affairs for muslims, and Civil } \\
\text { Registry Office for non-muslims to bind the } \\
\text { related third parties. }\end{array}$ \\
\hline 9. & $\begin{array}{l}\text { Marital agreement must be made before the } \\
\text { marriage is held with a Notary deed; if it is not } \\
\text { then it is considered null and void (van } \\
\text { rechtswege nietig) since the marriage takes } \\
\text { place, additional time should therefore not be } \\
\text { determined. }\end{array}$ & $\begin{array}{l}\text { A marital agreement can be made with post- } \\
\text { marital Notary deed based on Constitutional } \\
\text { Court Decision No. 69/PUU/XII/2015, which } \\
\text { then be recorded in the Office of Religious } \\
\text { Affairs for Muslims and Civil Registry } \\
\text { Office for non-muslims to bind the related } \\
\text { third parties. }\end{array}$ \\
\hline
\end{tabular}

Source: Third-Party Legal Protection to the Assets Separation Agreement after Constitutional Court Decision No. 69/PUU/XII/2015

Based on the reconstruction of legal protection to agreement of post-marital assets separation above, the publishment of Constitutional Court Decision No. 69/PUU/XII/2015 have a major impact on the law development in Indonesia, especially related to marital agreements and property rights in Indonesia. Ike Farida's case,[6] who filed a lawsuit to the MK, in the beginning it was unthinkable that the suit would be granted, after the lawsuit was decided by the Constitutional Court, it gives an impact on the status of Indonesian Citizens (WNI) who did intermarriage over material rights or property ownership. 
Constitutional Court Decision to grant some parts of the lawsuit has resulted in changes to the Indonesian marriage law. Marriage in Indonesia is regulated under Law Number 1 of 1974 concerning Marriage. Specifically related to marital agreements, it is regulated in Chapter V about Marital Agreements. Article 29 Paragraph (1) Law Number 1 of 1974 concerning Marriage emphasizes that a marital agreement can only be made before or during the marriage. This marital agreement is known as pre-nuptial agreementatau pre-marital agreement (pre-nupt).

In practice, often time a notary refuses to make a marital agreement due to the notary's lack of information that this is now allowed even though there is no implementing regulation yet. Marital agreements are binding on husband-wife and third parties when it is registered to the Office of Religious Affairs (KUA) for Muslims and Civil Registration Office (DISPENDUKCAPIL) according to its legal subject.

Based on Diagram 1 below, the writers made efforts to protect the concept of legal protection that will protect third party losses from any changes in marital agreements made after the marriage, in the form of a diagram that is called Diagram of the Third Party Legal Protection Concept illustrated in Figure 1 below.

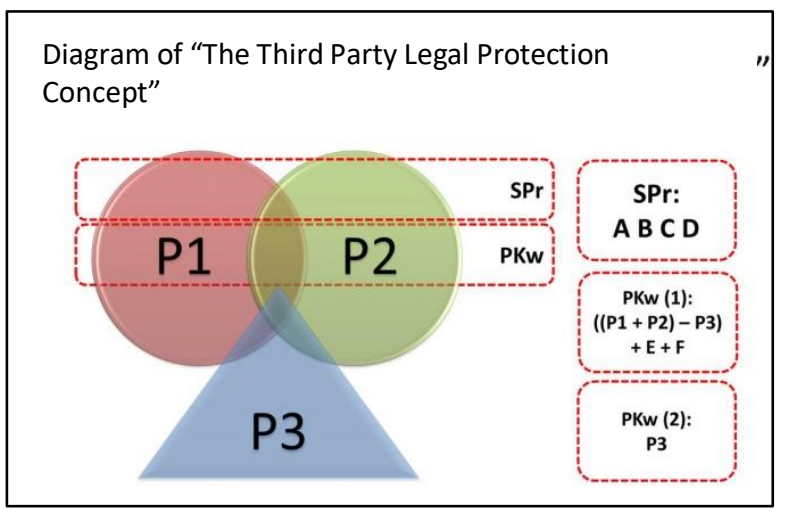

Figure 1.Diagram of the third party legal protection concept. Source: Writers

Figure 1 above shows the relationship between each element of the first, second, and third parties where the influence occurs if the assets separation is carried out after the marriage of the first and second parties that have different nationalities and live in Indonesia and give an impact to the third party.
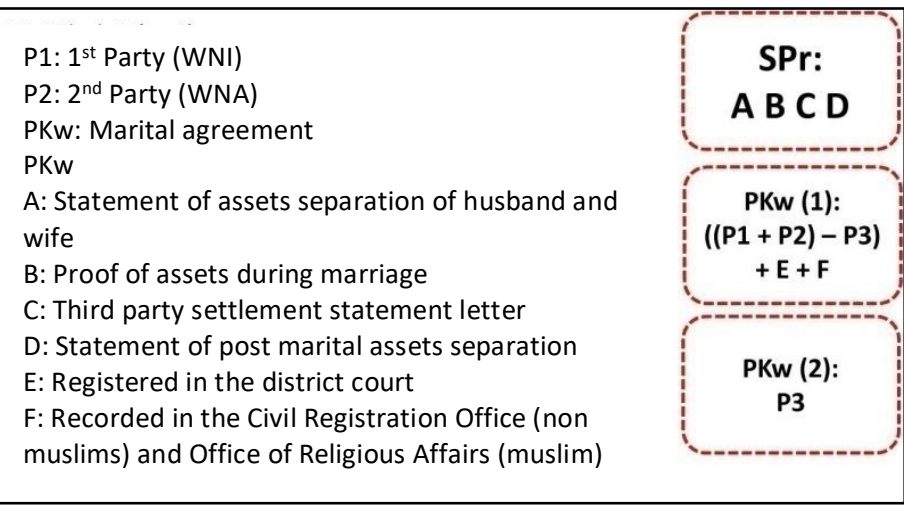

Figure 2. Design of the forming elements of the Third-Party Protection Concept

Figure 2 above explains that out of elements of $\mathrm{P} 1$ and $\mathrm{P} 2$, one of which is a foreign citizen and does a Marital Agreement (PKw). There are 3 main steps which form the basis of protection diagram above as follows: (1). SPr is documents that need to be prepared as 
requirements; $\mathrm{A}=$ Statement of assets separation of husband and wife, $\mathrm{B}=$ Proof of assets during marriage; $\mathrm{C}=$ Third party settlement statement letter; and $\mathrm{D}=$ Statement of post marital assets separation; (2). PKw (1) is a marital agreement that is done wherein the asset is divided after deducting obligations to the third party (P3) that has been through the process of registering in a district court (E) and recorded in the civil registration office for non-muslims and Office of Religious Affairs for muslims. While $\mathrm{PKw}(2)$ is a built-in concept that has secured the position of the third party.

\section{CONCLUSION}

The conclusions obtained from this research are: (a). Third-party legal protection of the for post-marital assets separation agreements bind husband-wife and third parties when the deed of marital agreement is requested for approval to the authorized District Court, furthermore, a deed of an assets separation agreement is made by Notary, and then it shall be recorded in the Office of Religious Affairs (KUA) for muslims, while for non-muslims, it is recorded in the Civil Registration Office (DISPENDUKCAPIL) according to its legal subject; (b). Building the concept of third party legal protection to post-marital assets separation agreements with post-marital assets separation agreements for the related third party because of the legal status of marriage assets of husband and wife that used to be joint assets becomes separated. The making of marital assets separation agreements must be accompanied by the following requirements: ID Card (KTP), Family Register (KK), Birth Certificate, Marriage Certificate, Annual Tax Return, Statement of Validity of Assests Inventory documents of each future husband and/or future wife with $\mathrm{Rp}$ 6,000.00 duty stamped, through Public Accountant, announced on the newspaper for 7 days, if there is no objection then the deed can be made. This deed of post-marital assets separation is then requested to be approved by the authorized District Court, subsequently, a Deed of Post-Marital Assets Separation will be recorded in the Office of Religious Affairs (KUA) for muslims, while for non-muslims, it is recorded in the Civil Registration Office (DISPENDUKCAPIL) to bind the third party. Aktaperjanjian pemisahan harta perkawinan ini dimohonkan penetapan ke Pengadilan Negeri yang berwenang, selanjutnya dibuatkan Akta Perjanjian Pemisahan Harta Perkawinan setelah itu dicatatkan pada Kantor Urusan Agama (KUA) bagi yang beragama Islam, sedangkan dicatatkan pada Dinas Kependudukan dan Catatan Sipil (DISPENDUKCAPIL) bagi yang beragama selain Islam supaya mengikat pihak ketiga tersangkut

\section{KEYNOTES}

1. Wirjono Prodjodikoro, 1981, Hukum Perdata Tentang Persetujuan-Persetujuan Tertentu Sumur, Bandung, page. 8

2. Mahkamah Konstitusi Republik Indonesia (1), Putusan Nomor 69/PUU-XIII/2015, p. 13, 16 dan 33

3. Sudikno Mertokusumo, 1988, Hukum Acara Perdata di Indonesia, Liberty, Yogyakarta, page. 97

4. J. Satrio, Hukum Harta Perkawinan, Citra Aditya, Bandung, page. 31

5. After Law of Marriage is promulgated (on $2^{\text {nd }}$ of January 1974/at least after Government Regulation Number 9 of 1975 takes effect) marital agreement is recorded in the Civil Registry Office or the Office of Religious Affairs

6. Ike Farida, Seorang Pelaku Kawin Campur Mengajukan Gugatan Ke Mahkamah Konstitusi Pada Tahun 2017 


\section{REFERENCES}

[1] Atwood, Barbara A., et al. Discussion Paper No . 13-02 Agreements A New Uniform Law for Premarital and Marital Agreements. no. 13, 2013.

[2] Bix, Brian. "Agreements in Family Law." SSRN Electronic Journal, no. 12, 2012, doi: $10.2139 /$ ssrn.2125343.

[3] Efe, C. J. (2019) 'The Need for the Statutory Introduction of the Concept of "Matrimonial Property" in Nigeria', Journal of African Law, 63(1), pp. 105-125. doi: $10.1017 / \mathrm{S} 0021855319000093$.

[4] Hildebrandt, Mireille. Supranational Law. 2019.

[5] Ii, I., Et Al. Legal Rules And Cultural Bias: When Are Intimate Partnerships With A Foreigner Considered "Insincere ” By Israeli Authorities ? Pp. 1-27.

[6] Li, L. (2014) 'Be prepared in advance: A case for allowing binding prenuptial agreements in Hong Kong', International Journal of Law, Policy and the Family, 28(3), pp. 339-362. doi: 10.1093/lawfam/ebu003.

[7] Jules, Adrienne Hunter, and Fernanda Nicola. "The Contractualization of Family Law in the United States." American Journal of Comparative Law, vol. 62, no. 1, 2014, pp. 15184, doi:10.5131/ajcl.2013.0022.

[8] Mahkamah Konstitusi Republik Indonesia (1), Putusan Nomor 69/PUU-XIII/2015, p. 13, 16 dan 33.

[9] Mertokusumo, S. (1988). Hukum Acara Perdata di Indonesia. Yogyakarta: Liberty.

[10] Prodjodikoro, W. (1981). Hukum Perdata Tentang Persetujuan-Persetujuan Tertentu. Bandung: Sumur.

[11] Satrio, J. (1991). Hukum Harta Perkawinan. Bandung: Citra Aditya.

[12] Siliquini-Cinelli, Luca, and Andrew Hutchison. "The Constitutional Dimension of Contract Law: A Comparative Perspective." The Constitutional Dimension of Contract Law: A Comparative Perspective, 2017, doi:10.1007/978-3-319-49843-0.

[13] Swennen, F. (ed. ). (2015) 'Contractualisation of Family Law - Global Perspectives', p. 372. doi: 10.1007/978-3-319-17229-3. 